\title{
Sosyal Bilgiler Öğretmen Adaylarının Yansıtıcı Düşünme Eğilimleri
}

\author{
The Reflective Thinking Tendency of Social Studies Candidate Teachers
}

\author{
Hatice GEDIK* \\ Nadire Emel AKHAN ${ }^{* *}$ \\ Gökçe KILIÇOĞLU***
}

$\ddot{O}_{z}: \mathrm{Bu}$ araştrımanın amacı, Sosyal Bilgiler öğretmen adaylarının yansıtıcı düşünme eğilimlerini belirlemek ve çeşitli değişkenler açısından ortaya koymaktır. Araştırmada, öğretmen adaylarının yansıtıcı düşünme eğilimlerini belirlemek amacıyla, Semerci (2007) tarafindan geliştirilen "Öğretmen ve Öğretmen Adayları İçin Yansıtıcı Düşünme Eğilimi (YANDE) Ölçeğì" ve öğrencilerin demografik özelliklerini belirlemek için araştırmacılar tarafından hazırlanan "Kişsisel Bilgi Formu" kullanılmıștır. Tarama modelinin kullanıldığı araştırmanın örneklemini, Türkiye'nin değişik bölgelerinden seçkisiz olmayan örneklem türlerinden amaçsal örnekleme ile belirlenmiş üniversitelerdeki eğitim fakültelerinin Sosyal Bilgiler Öğretmenliği 3. ve 4. sınıflarında öğrenim gören öğretmen adayları oluşturmaktadır. Elde edilen veriler SPSS programında değerlendirilmiştir. Araştırma sonuçlarına göre öğretmen adaylarının yansıtıcı düşünce eğilimlerinin orta düzeyde olduğu belirlenmiştir. Ayrıca öğretmen adaylarının yansıtıcı düşünce eğilimlerinin cinsiyet, aile gelir durumu ve mezun olunan lise türüne göre anlamlı fark göstermediği, ancak $Y A N D E$ ölçeği alt boyutlarından bazılarında farklılıklara rastlandığı görülmüştür.

Anahtar sözcükkler: Yansıtıcı düşünme, öğretmen adayı, yansıtıcı öğrenme, yansıtıcı öğretmen

Abstract: The aim of this study was to determine the reflective thinking tendencies of prospective social studies teachers and to determine this tendency in terms of various variables. The "Reflective Thinking Tendency Scale (RTTS) for teachers and student teachers", which was developed by Semerci (2007) to determine the reflective thinking tendencies of prospective social studies teachers; together with the "Personal Information Form", developed by the researchers to obtain demographic information concerning students, were employed in this study. The sample in the study was formed of $3^{\text {rd }}$ and $4^{\text {th }}$ grade candidate teachers studying at social studies teaching departments of education faculties of some universities, chosen through the method of purposeful sampling in different regions of Turkey. The survey model was used in the present study and the data was analysed using SPSS software. The results of this research indicated the reflective thinking tendencies of candidate teachers were of the medium level. Further, it was determined that the reflective thinking tendencies of the participants showed no significant differences from variables such as: gender, the monthly income of the family and the type of high school, there were however differences in some of the sub-dimensions on the Reflective Thinking Tendency Scale.

Keywords: Reflective thinking, candidate teacher, reflective learning, reflective teacher

\footnotetext{
*Yrd. Doç. Dr., Aksaray Üniversitesi Eğitim Fakültesi Sosyal Bilgiler Eğitimi A.B.D., htcgedik@gmail.com

** Yrd. Doç. Dr., Akdeniz Üniversitesi, Eğitim Fakültesi, Sosyal Bilgiler Eğitimi A.B.D., neakhan@akdeniz.edu.tr

*** Öğr. Gör. Dr., Gazi Üniversitesi, Eğitim Fakültesi, Sosyal Bilgiler Eğitimi A.B.D., gokcekilicoglu@gmail.com Bu makale II. Uluslararası Sosyal Bilgiler Eğitimi Sempozyumu’nda (Nisan / 2013) sözlü bildiri olarak sunulmuştur.
} 


\section{Giriş}

Gelişen ve değişen dünya şartları varlığını güçlü bir şekilde ortaya koyabilecek düşünen insan istemektedir. Çünkü ancak düşünen, yani üst düzey zihinsel becerilerini kullanabilen insan gelecekte daha başarılı olacaktır. Bugün ve gelecek zamanda artık bu bir zorunluluk olarak kendisini hissettirmektedir (Semerci, 1999). Bu durumdan hareketle günümüzde eğitimin en önemli amaçlarından biri öğrenenlerin bilgiyi düşünerek ve bilinçli şekilde edinmelerini; bu bilgileri karşılaştıkları problemlerin çözümünde kullanabilmelerini, bu bilgilerden hareketle yeni bilgiler üretebilmelerini sağlamak olmuştur. Dewey (1957), insanların düşünme yeteneğiyle doğduğunu ve eğitimcilerin en önemli görevinin bu potansiyel yeteneği en üst düzeye çıkarmak olduğunu belirtmiştir (akt. Karadağ, 2010). Doğru düşünme yollarının kazanılması, öğrencilere edindiği bilgileri kullanmada, problem çözmede, gerek günlük yaşamlarında gerekse derslerde başarılı olmalarında katkı sağlayacaktır. Bu becerilerin öğrencilere kazandırılabilmesi için, öncelikli olarak öğretmenlerin düşünme becerilerine sahip olmaları ve bu becerileri sürekli geliştirip kullanabiliyor olmaları gerekmektedir (Duban, \& Yelken, 2010). Bu becerilerin en önemlilerinden biri de yansitıcı düşünme becerisidir.

Norton'a (1994) göre yansıtıcı düşünen bir birey sorunların çözümüne yönelik kararlar almakta, aldığı bu kararları eyleme koymakta ve sonuçlarını tekrar değerlendirmektedir. Buna göre yansıtıcı düşünme; karşılaşılan problemi çözmeye dayanan bir araştırma, bireyin yeni fikirler üretmesini teşvik etme boyutuyla yaratıcı, kendini değerlendirme boyutuyla eleştirel, önceki deneyimler ile bağlantı kurma, öğrenme üzerine düşünme ve kendi düşüncesini düşünme boyutuyla biliş üstü düşünme süreciyle birebir örtüşen bir beceridir (akt. Yorulmaz, 2006).

Yansitıcı düşünme denilince akla gelen ilk isim John Dewey'dir. Dewey pragmatik felsefe ve eğitim üzerinde durmuştur ve genellikle düşünme kavramının kaynağı olarak bilinir. Dewey, eğitimde demokrasiyi vurgulamıştır. Onun için, öğrenciler okulda demokrasiyi öğrenmeden aynı zamanda yetişkinlerin de ihtiyacı olan problem çözme becerisini asla öğrenemezler. Demokratik okullarda problem çözme becerisinin kazandırılmasının yanında yansıtıcı düşünme de kazandırılması gereken becerilerden biridir (Genç, 2004).

Yansıtıcı düşünme kendiliğinden gelişen bir düşünme türü değildir. Yansıtıcı düşüncede, zihin bir probleme odaklanarak düşünce bilinçli ve aktif bir sürece girer. Bu özelliğiyle yansıtıcı düşünme günlük düşünce ve eylemlerden ayrılmaktadır (Alp, \& Taşkın, 2008). Literatür incelendiğinde yansıtıcı düşünmenin çeşitli tanımlarına rastlamak mümkündür. Dewey (1933), yansıtıcı düşünmeyi, uygulamacıların pratik sorunlarıyla ilgilenen, bunlara uygun ve gerçekçi çözümler üretmeye çalışan etkin, amaçlı ve istikrarlı düşünme süreci şeklinde açıklarken (Akt. Ekiz, 2006), Schön (1983) kişinin eylem sırasında ne yaptığını sorgulaması, daha sonra yaptığı üzerinde tekrar düşünmesi ve buna göre genel bilgilerini düzenlemesi olarak ifade etmektedir (akt. Durdukoca, \& Demir, 2012; 358). Yansitıcı düşünce, Atay'a (2003) göre, herhangi bir deneyimin hatırlandığı, üzerinde düşünüldüğü ve genellikle belli bir amaç göz önüne alınarak değerlendirildiği süreç şeklinde, Öztürk (2003) tarafından problemi saptamak ve farklı açılardan bu probleme bakmayı gerektiren bir süreç olarak, Ünver (2004) tarafindan ise bireyin öğretme ya da öğrenme yöntemi ve düzeyine ilişkin olumlu ve olumsuz durumları ortaya çıkarmaya ve sorunları çözmeye yönelik düşünme süreci olarak tanımlamaktadır.

Dewey (1957), yansıtıcı düşünmeyi dört boyutta ele alınmaktadır (akt. Karadağ, 2010):

1. Yansitıcı düşünmede görüşler arasında anlamlı ilişkilere dayanan bir ardışıklık vardır. Bir görüss kendinden önceki görüşe dayanır ve kendinden sonraki görüşün uygunluğunu belirler.

2. Yansitıcı düşünmede olgu ve olayların temeli duygular ve inançlardır.

3. Yansitıcı düşünmede inancın dayanak noktası bulgulardır. $\mathrm{Bu}$ bulgulara göre 
düşünceler uygun olup olmama koşuluna göre kabul veya reddedilir.

4. Yansitıcı düşünme, karşılaşılan problemi çözmeye dayanan bir araştırma sürecidir.

Yeni ilköğretim programında yapılandırmacı yaklaşımın anlamlı ve kalıcı öğrenmeyi sağlama, yansitıcı düşüncenin ise bilimsel düşünme ve karar verme becerilerini geliştirme amaciyla temel alındığ 1 ve birbirini desteklediği görülmektedir. Bununla birlikte, program hem öğrencilerin hem de öğretmenlerin yansıtıcı düşünce becerilerini kullanmalarına ve geliştirmelerine yönelik etkinlikler içermektedir (Alp, \& Taşkın, 2008). Eğitim programının yansıtıcı düşünme becerisini kullanmaya yönelik olarak hazırlanmıştır. Bununla beraber eğitimin en önemli öğelerinden biri olan öğretmenlerin bu beceriye sahip olmaları, donanımları ve nasıl yetiştirildiği konusu önem kazanmaktadır (Üstün, 2011). İlköğretim programının öğrencilerde yansıtıcı düşünme becerisini geliştirmeyi hedeflediği ve etkililiğinin öğretmenlerin yansıtıcı düşünme becerilerine bağlı olduğu söylenebilir.

Yansıtıcı düşünmenin bilinçli bir şekilde öğrenilen ve geliştirilen bilişsel bir özellik olduğu düşünülürse, bu becerinin okul ortamında kazandırılması çok önemlidir. Eğitim öğretim sürecinde uygun ortam ve yeterli rehberlikle bireylere düşünme becerilerini kazandırabilecek en yetkin kişi ise öğretmendir (Üstün, 2011). Araştırmacılar, öğretmenlerin kendi öğretimlerini yansıtmalarının, onların uygulamalarını ve problem çözme becerilerini geliştireceğini ortaya koymaktadırlar (Dewey, 1933; Schön, 1983; Yost, et alii, 2000, akt. Köksal, \& Demirel, 2008, 190). Ayrica eğitim-öğretim süreci içinde yansıtıcı düşünce, öğretmenin öğrenme-öğretme yöntemi ve düzeyine ilişkin olumlu ya da olumsuz durumları ortaya çıkarmaya ve sorunları çözmeye yönelik düşünme sürecidir. Öğretmenler mesleğiyle ilgili kendini geliştirme sürecinde diğer meslektaşlarıyla sürekli iletişim halinde olmalıdırlar. Çünkü deneyimlerini paylaşmaları ve sürekli olarak fikir alışverişinde olmaları öğretmenlerin kendilerini ve diğer meslektaşlarını değerlendirmelerini, dolayısıyla da geliştirmelerini sağlamaktadır. Kısacası yansıtıcı düşünme, hem öğretmenlerin hem de öğrencilerin, öğrenme süreçlerinin vazgeçilmez bir unsurudur (Ünver, 2004).

Yansıtıcı düşünmede öğretmenlerden öğrenciyi sürece yönelik olarak değerlendirmeleri, öğretim sürecinde yapılanları kaydetmeleri ve sürekli olarak bu kayıtları geriye dönüp kontrol ederek gözden geçirmeleri beklenmektedir. Yapılandırmacı yaklaşımda öğretmenden beklenen özelliklerin yansıtıcı düşünen öğretmenin sahip olması gereken özelliklerle benzerlik olduğunu söyleyebilir. Yani yapılandırmacı yaklaşımı uygulayan bir öğretmen yansıtıcı düşünme becerilerine de sahip olabilir (Güvenç, 2012).

Yansıtıcı düşünmenin uygulanmasında ve bu becerinin kazandırılmasında en önemli rol öğretmene aittir. Yansıtıcı düşünme becerisini öğrencilere kazandırmak için öncelikle öğretmenlerin bu beceriyi kendisinde içselleştirmiş olması gerekmektedir. Öğretmenler demokratik bir sınıf ortamı hazırlayarak öğrencilerin tüm beceri ve yeteneklerini ortaya çıkarabilirken onları sınıfta pasif hale getirerek yeteneklerinin körelmesine neden olabilmektedir (Karadağ, 2010). Yansitıc1 düşünme becerisine sahip öğretmenler; öğrencilerinin problem çözme becerileriyle donanmış olmasını, hem birbirlerine hem de çevrelerine karşı duyarlı, anlayışlı ve önyargısız bir bakış açısıyla davranmalarını isterler. Yansıtıcı öğretmenler öğretimde rehberdirler. Bu bağlamda yansıtıcı öğretmenler öğrencilerinin edinmek istedikleri bilgiye ulaşmalarında yol gösterir ve öğrencilerinin düşüncelerini özgürce paylaşabilecekleri ortamlar oluştururlar (Ersözlü, 2008).

Bu bilgiler 1şığında, yapılandırmacı yaklaşım içinde yer alan yansıtıcı düşüncenin öğrenmeöğretme sürecinde kullanılmasının bir gereklilik olduğu söylenebilir. Bu durumda öğretmenlerin öğrenme-öğretme sürecinde sınıf içi uygulamaları yorumlamaları, uygulama sırasında aldıkları kararları etkileyen faktörleri bilinçli bir şekilde ifade etmeleri ve uygulamalarını sürekli geliştirme çabasında olmaları gerekmektedir (Alp, \& Taşkın, 2008). 
Öğretmen adayları mezun olup öğretmenliğe başladıklarında fakültede öğrendikleri bilişsel bilgilerle gerçek uygulamalar arasında bağlantı kurmakta ve karşılaştıkları sorunlara uygun çözüm yolları bulmakta çeşitli sıkıntılarla karşılaşmaktadırlar. Hâlbuki öğretmen adaylarının uygulamalarda karşılaştıkları sorunları çözebilme becerisine sahip olmaları gerekmektedir. Öğretmen eğitiminde yansıtıcı öğretim, bilişsel bilgi ile uygulama arasında köprü kurulmasına katk1 sağladığı için önemlidir (Altınok, 2002).

İlgili literatür tarandığında yansıtıcı düşünme ile ilgili yapılan çalışmaların öğretmen ve öğretmen adaylarının yansıtıcı düşünme becerilerine ve yansıtıcı düşünme etkinliklerine odaklanıldığ1 görülmektedir (Kirk, 2000; Oruç, 2000; Langer, 2002; Lee, 2005; Ekiz, 2006; Erginel, 2006; Yorulmaz, 2006; Kozan, 2007; Ersözlü, 2008; Aslan, 2009; Şahin 2009; Duban \& Yelken, 2010; Hasırc1, \& Sadık, 2011; Şahan, \& Kalkay, 2011; Aydın, \& Çelik, 2013). Bu çalışmada ise Sosyal Bilgiler öğretmen adaylarının yansıtıcı düşünme eğilimleri belirlenmeye çalışılmıştır. Bu amaç doğrultusunda araştırmada şu sorulara cevap aranmıştır:

1. Sosyal Bilgiler öğretmen adaylarının Öğretmen ve Öğretmen Adayları İçin Yansitıcı Düşünme Eğilimi $(Y A N D E)$ Ölçeğine göre yansıtıcı düşünme eğilimleri düzeyleri nedir?

2. Sosyal Bilgiler öğretmen adaylarının $Y A N D E$ ölçeğine göre yansıtıcı düşünme eğilimleri cinsiyet, aile gelir durumu ve mezun olunan lise değişkenlerine göre farklılık göstermekte midir?

\section{Yöntem}

$\mathrm{Bu}$ çalışmada Sosyal Bilgiler öğretmen adaylarının Yansıtıcı Düşünme Eğilimlerini (YANDE) incelemek amacıyla tarama modeli kullanılmıştır. Tarama modeli, Karasar'a $(2003,77)$ göre, araştırmanın konusu olan bireylerin veya durumların, geçmişte veya halen bulundukları koşullar içinde doğal halleri ile belirlendiği yaklaşımlarıdır.

\section{1. Çalışma Grubu}

Araştırmanın çalışma grubunu, 2012-2013 eğitim-öğretim yılında, Türkiye'nin farklı üniversitelerinde öğrenim gören 1219 Sosyal Bilgiler 3. ve 4. sınıflarında öğrenim gören öğretmen adayları oluşturmaktadır. Öğretmen adaylarına ait bilgiler Tablo 1'de verilmiştir.

Tablo 1. Çalışma Grubundaki Öğretmen Adaylarına Ait Bilgiler

\begin{tabular}{|l|c|c|l|c|c|}
\hline Cinsiyet & $\mathbf{n}$ & $\mathbf{\%}$ & Üniversite & $\mathbf{n}$ & $\mathbf{\%}$ \\
\hline K1z & 607 & 49.8 & Abant İzzet Baysal Ünv. & 105 & 8.6 \\
\hline Erkek & 612 & 50.2 & Adnan Menderes Ünv. & 157 & 12.9 \\
\hline Gelir & $\mathbf{n}$ & $\mathbf{\%}$ & Akdeniz Ünv. & 120 & 9.8 \\
\hline 700 ' den az & 299 & 24.5 & Aksaray Ünv. & 87 & 7.1 \\
\hline $701-1500$ & 541 & 44.4 & Amasya Ünv. & 83 & 6.8 \\
\hline $1501-2500$ & 294 & 24.1 & Güney Doğu Ünv. & 79 & 6.5 \\
\hline $2501+$ & 85 & 7.0 & Gazi Osman Paşa Ünv. & 90 & 7.4 \\
\hline Anne Ĕgitim & $\mathbf{n}$ & $\mathbf{\%}$ & Gazi Ünv. & 82 & 6.7 \\
\hline Okuma-Yazma Bilmiyor & 235 & 19.3 & Kafkas Ünv. & 85 & 7.0 \\
\hline Okur-yazar & 130 & 10.7 & Dumlupınar Ünv. & 73 & 6.0 \\
\hline İlkokul & 575 & 47.2 & Marmara Ünv. & 81 & 6.6 \\
\hline Ortaokul & 129 & 10.6 & Muğla Ünv. & 92 & 7.5 \\
\hline Lise & 99 & 8.1 & Van 100. Y1l Ünv. & 85 & 7.0 \\
\hline Üniversite & 51 & 4.2 & Toplam & $\mathbf{1 2 1 9}$ & $\mathbf{1 0 0}$ \\
\hline Baba Ĕgitim & $\mathbf{n}$ & $\mathbf{\%}$ & & & \\
\hline Okuma-Yazma Bilmiyor & 32 & 2.6 & Mezun olduğu Lise & & \\
\hline
\end{tabular}


Sosyal Bilgiler Öğretmen Adaylarının Yansıtıcı Düşünme Eğilimleri

\begin{tabular}{|l|c|c|l|c|c|}
\hline Okur-yazar & 124 & 10.2 & Düz Lise & 1120 & 91.9 \\
\hline İlkokul & 540 & 44.3 & Fen Lisesi & 18 & 1.5 \\
\hline Ortaokul & 210 & 17.2 & Sosyal Bilimler Lisesi & 30 & 2.5 \\
\hline Lise & 217 & 17.8 & Meslek Lisesi & 37 & 3.0 \\
\hline Üniversite & 96 & 7.9 & Diğer & 14 & 1.1 \\
\hline Toplam & $\mathbf{1 2 1 9}$ & $\mathbf{1 0 0}$ & Toplam & $\mathbf{1 2 1 9}$ & $\mathbf{1 0 0}$ \\
\hline
\end{tabular}

Çalışmada seçkisiz olmayan örneklem türlerinden amaçsal örnekleme tercih edilmiştir. Çalışmanın tüm evrene genellenebilmesi için Türkiye'nin her bölgesinden farklı üniversiteler seçilmiştir. Araştırmaya katılan öğretmen adaylarının \%49'8'i kız, \%50.2'si erkek öğrencidir. Öğrencilerin gelir dağılımına bakıldığında genel olarak gelir düzeylerinin 701-1500 tl $(\% 44,3)$ ve 701 tl'den daha az olduğu (\%24,7) görülmektedir. Öğretmen adaylarının anne eğitim $(\% 47,2)$ ve baba eğitim durumları $(\% 44,3)$ genel olarak ilkokul mezunu oldukları görülmektedir. Öğretmen adaylarının mezun oldukları lise türü incelendiğinde tamamına yakınının düz lise (\% 91.9), fen lisesi (\%1.5), sosyal bilimler lisesi (\%2.5), meslek lisesi (\%3.0) ve diğer lise türlerinden (\%1.1) olduğu görülmektedir.

\subsection{Verilerin Toplanması ve Analizi}

Çalışma grubundaki öğretmen adaylarının yansıtıcı düşünme eğilimlerini belirlemek amacıyla, Semerci (2007) tarafından geliştirilmiş ve geçerlik güvenirlik çalışması yapılmış olan "Öğretmen ve Öğretmen Adayları için Yansitıcı Düşünme Ĕ̈ilimi (YANDE)" ölçeği veri toplama arac1 olarak kullanılmıştır. YANDE ölçeği, "sürekli ve amaçlı düşünme", "açık fikirlilik", "sorgulayıcı ve etkili ögretim", "ögretim sorumluluğu ve bilimsellik", "araştırmacı", "öngörülü ve içten olma" ve "mesleğe bakış" olmak üzere 7 alt boyuttan ve 20'si olumsuz, 15'i olumlu toplam 35 maddeden oluşmaktadır. Likert tipinde hazırlanan ölçeğin derecelendirilmesi, "Tamamen katıllyorum" (5), "Çoğunlukla katıllyorum" (4), "Kısmen katıllyorum" (3), "Çoğunlukla katılmıyorum" (2), "Hiç katılmıyorum" (1) şeklindedir. Araştırmadan elde edilen verilerin analizinde SPSS istatistik paket programı kullanılmıştır

Bağımsız değişkenlere göre görüşler arasındaki farkın manidarlığı, grup sayısının iki olduğu durumlarda Mann Whitney U, ikiden fazla olduğu durumlarda Kruskal Wallis testi ile hesaplanmış ve hesaplanan $\mathrm{z}$ ve $\mathrm{x}^{2}$ değerleri $\mathrm{p}<0,05$ manidarlık düzeyinde yorumlanmıştır.

Mann-Whitney U testi ve Kruskal Wallis H testi kullanımının amacı, katılımcıların ölçeğe vermiş oldukları cevaplardan elde edilen sonuçların, Kolmogorov-Smirnov (K-S) normallik testine göre normal bir dağılım göstermemiş olmasından dolayı parametrik olmayan testler kullanılmıştır.

YANDE ölçeğinde toplam ve her bir alt boyuttan alınabilecek maksimum puanların hesaplanmasında kullanılan aralıklar tespit edilmişsir. Bu aralıklar Tablo 2'de belirtilmişstir.

Tablo 2. Sosyal Bilgiler Öğretmen Adaylarının YANDE Ölçeğinde Düzeylerinin Belirlenmesinde Kullanılan Puan Değerleri ve Her Bir Alt Boyuttan Alınabilecek Minimum ve Maksimum Puanlar

\begin{tabular}{|l|c|c|}
\hline YANDE Boyutları & Soru Sayısı & Puan Aralığı \\
\hline Sürekli ve Amaçlı Düşünme & 7 & $7-35$ \\
\hline Açı Fikirlilik & 6 & $6-30$ \\
\hline Sorgu ve Etkili Öğretim & 5 & $5-25$ \\
\hline Öğretim Sorumluluğu ve Bilimsellik & 5 & $5-25$ \\
\hline Araştırmacı & 6 & $6-30$ \\
\hline
\end{tabular}




\begin{tabular}{|l|c|c|}
\hline Öngörülü ve İçten Olma & 4 & $4-20$ \\
\hline Mesleğe Bakış & 2 & $2-10$ \\
\hline Toplam & 35 & $35-175$ \\
\hline
\end{tabular}

Standartlaştırılmış puana göre en yüksek yansıtıcı düşünme eğilimi düzeyi 175 puan olarak en düşük yansıtıcı düşünme eğilimi düzeyi de 35 puan olarak tespit edilmiştir. En yüksek puan ile en düşük puan arasındaki fark alınıp, düşük, orta ve yüksek olmak üzere üç kategoriye alındığı için üç eşit parçaya bölünür. Elde edilen değer bu kategorilerin puan aralıklarının oluşumunda kullanılır. Buna göre 35-81 puan aras1 düşük, 82-128 aras1 orta 129-175 puan aras1 yüksek yansıtıcı düşünme eğilimi düzeyini göstermektedir. Aynı durum $Y A N D E$ ölçeğinin alt boyutları için de uygulanmıştır. Diğer bir ifade ile açıklamak gerekirse "Sürekli ve Amaçlı Düşünme" alt boyutundan alınabilecek en düşük puan 7, en yüksek puan ise 35 'dir. "Açık fikirlilik" alt boyutundan alınabilecek en düşük puan 6, en yüksek puan ise 30'dur. "Sorgu ve Etkili Öğretim" alt boyutundan alınabilecek en düşük puan 5, en yüksek puan ise 25 'dir. "Öğretim Sorumluluğu ve Bilimsellik" alt boyutundan alınabilecek en düşük puan 5, en yüksek puan ise 25 'dir. "Araştırmacl" alt boyutundan alınabilecek en düşük puan 6, en yüksek puan ise 30 'dur. "Öngörülü ve İçten Olma" alt boyutundan alınabilecek en düşük puan 4, en yüksek puan ise 20'dir. "Mesleğe Bakış" alt boyutundan alınabilecek en düşük puan 2, en yüksek puan ise 10 'dur.

\section{Bulgular}

2.1. Sosyal Bilgiler öğretmen adaylarının, Öğretmen ve Öğretmen Adayları İçin Yansıtıcı Düşünme Eğilimi (YANDE) Ölçeğine göre yansıtıcı düşünme eğilimlerinin düzeyi nedir?

Tablo 3. Sosyal Bilgiler Öğretmen Adaylarının Yansıtıcı Düşünme Eğilimi Ölçeği Düzeylerine İlişkin Bulgular

\begin{tabular}{|c|c|c|c|c|c|c|}
\hline$Y A N D E$ Alt Bileşenleri & & Düşük & Orta & Yüksek & $\bar{X}$ & $\mathbf{S}$ \\
\hline \multirow{3}{*}{ Sürekli ve Amaçlı Düşünme } & Aralık & $1-11$ & $12-23$ & $24-35$ & \multirow{3}{*}{20.0} & \multirow{3}{*}{3.30} \\
\hline & $\mathrm{f}$ & 7 & 1081 & 131 & & \\
\hline & $\%$ & .57 & 88.67 & 10.74 & & \\
\hline \multirow{3}{*}{ Açık Fikirlilik } & Aralık & $1-10$ & $11-20$ & $21-30$ & \multirow{3}{*}{9.5} & \multirow{3}{*}{4.66} \\
\hline & f & 876 & 293 & 50 & & \\
\hline & $\%$ & 71.86 & 24.03 & 4.10 & & \\
\hline \multirow{3}{*}{ Sorgulayıcı ve Etkili Öğretim } & Aralık & $1-8$ & $9-17$ & $18-25$ & \multirow{3}{*}{7.36} & \multirow{3}{*}{3.05} \\
\hline & $\mathrm{f}$ & 901 & 301 & 17 & & \\
\hline & $\%$ & 73.91 & 24.69 & 1.39 & & \\
\hline \multirow{3}{*}{ Öğretim Sorumluluğu ve Bilimsellik } & Aralık & $1-8$ & $9-17$ & $18-25$ & \multirow{3}{*}{14.84} & \multirow{3}{*}{2.56} \\
\hline & $\mathrm{f}$ & 19 & 1114 & 86 & & \\
\hline & $\%$ & 1.55 & 91.38 & 7.05 & & \\
\hline \multirow{3}{*}{ Araştırmacı } & Aralık & $1-10$ & $11-20$ & $21-30$ & \multirow{3}{*}{19.56} & \multirow{3}{*}{2.99} \\
\hline & $\mathrm{f}$ & 15 & 675 & 529 & & \\
\hline & $\%$ & 1.23 & 55.37 & 43.39 & & \\
\hline \multirow{3}{*}{ Öngörülü ve İçten Olma } & Aralık & $1-6$ & $7-13$ & $14-20$ & \multirow{3}{*}{16.65} & \multirow{3}{*}{3.41} \\
\hline & $\mathrm{f}$ & 13 & 199 & 1007 & & \\
\hline & $\%$ & 1.06 & 16.32 & 82.60 & & \\
\hline \multirow{3}{*}{ Mesleğe Bakış } & Aralık & $1-3$ & $4-7$ & $8-10$ & \multirow{3}{*}{3.42} & \multirow{3}{*}{1.93} \\
\hline & $\mathrm{f}$ & 785 & 369 & 65 & & \\
\hline & $\%$ & 64.39 & 30.27 & 5.33 & & \\
\hline
\end{tabular}




\section{Toplam}

\begin{tabular}{|c|c|c|c|c|c|} 
Aralık & $35-81$ & $82-128$ & $129-175$ & & \multirow{2}{*}{9} \\
\cline { 1 - 5 } $\mathrm{f}$ & 147 & 1063 & 9 & 91.40 & 9.85 \\
\hline$\%$ & 12.05 & 87.20 & .73 & & \\
\hline
\end{tabular}

Tablo 3 incelendiğinde elde edilen bulgulara göre Sosyal Bilgiler öğretmen adaylarının yansıtıcı düşünme eğilimi toplam puanının, belirlenmiş olan beşli değerlendirme kriterine göre $(\bar{X}=$ 91.40) orta olduğu belirlenmiştir. Elde edilen bu sonuca göre Sosyal Bilgiler öğretmen adaylarının, yansıtıcı düşünme eğilimlerinin "orta düzeyde" olduğu söylenebilir.

Sosyal Bilgiler öğretmen adaylarının yansıtıcı düşünme eğilimi ölçeğinin alt boyutlarından aldıkları puanlara göre değerlendirdiğimizde, "Sürekli ve amaçlı düşünme" alt boyutuna göre orta $(\bar{X}=20.00)$ seviyede, "Açık fikirlilik" alt boyutuna göre düşük $(\bar{X}=9.5)$ seviyede, "Sorgulayıcı ve etkili ögretim" alt boyutuna göre düşük $(\overline{\mathrm{X}}=7.36)$ seviyede, "Öğretim sorumluluğu ve bilimsellik" alt boyutuna göre orta $(\overline{\mathrm{X}}=14.84)$ seviyede, "Araştırmacı" alt boyutuna göre yüksek ( $\overline{\mathrm{X}}=19.56$ ) seviyede, "Öngörülü ve içten olma” alt boyutuna göre yüksek $(\bar{X}=16.65)$ seviyede ve "Mesleğe bakış" alt boyutunda ise orta $(\bar{X}=3.42)$ seviyede olduğu belirlenmiştir.

Tablo 4. Sosyal Bilgiler Öğretmen Adaylarının $Y A N D E$ Ölçeği Sürekli ve Amaçlı Düşünme Alt Boyutuna Ait Görüşleri

\begin{tabular}{|c|c|c|c|c|c|c|c|c|c|c|c|}
\hline \multirow[b]{2}{*}{ Maddeler } & \multicolumn{2}{|c|}{$\begin{array}{l}\text { Hiç } \\
\text { Katılmıyorum }\end{array}$} & \multicolumn{2}{|c|}{$\begin{array}{l}\text { Çoğunlukla } \\
\text { Katılmıyorum }\end{array}$} & \multicolumn{2}{|c|}{$\begin{array}{l}\text { Kismen } \\
\text { Kat1liyorum }\end{array}$} & \multicolumn{2}{|c|}{$\begin{array}{l}\text { Çoğunlukla } \\
\text { Katılıyorum }\end{array}$} & \multicolumn{2}{|c|}{$\begin{array}{l}\text { Tamamen } \\
\text { Katıliyorum }\end{array}$} & \multirow{2}{*}{$\bar{x}$} \\
\hline & f & $\%$ & f & $\%$ & f & $\%$ & f & $\%$ & f & $\%$ & \\
\hline $\begin{array}{l}\text { 1. Öğrencilerimin } \\
\text { görüşlerine değer } \\
\text { vermem. }\end{array}$ & 1024 & 84 & 78 & 6.4 & 35 & 2.9 & 26 & 2.1 & 56 & 4.6 & 4.63 \\
\hline $\begin{array}{l}\text { 2. Kendimi öğretim } \\
\text { hedeflerimin 1şı̆ğnda } \\
\text { eleştirel düşünürüm. }\end{array}$ & 31 & 2.5 & 92 & 7.5 & 254 & 20.8 & 410 & 33.6 & 432 & 35.4 & 3.92 \\
\hline $\begin{array}{l}\text { 3. Öğretimle ilgili } \\
\text { diğer öğretmenlere } \\
\text { yardımcı olurum. }\end{array}$ & 46 & 3.8 & 121 & 9.9 & 198 & 16.2 & 426 & 34.9 & 428 & 35.1 & 3.88 \\
\hline $\begin{array}{l}\text { 4.Kendi öğretimimin } \\
\text { etkililiğini } \\
\text { değerlendirmem. }\end{array}$ & 677 & 55.5 & 254 & 20.8 & 129 & 10.6 & 98 & 8.0 & 61 & 5.0 & 4.14 \\
\hline $\begin{array}{l}\text { 5. Sınıfta tartışmayı } \\
\text { teşvik eder yönetirim. }\end{array}$ & 119 & 9.8 & 136 & 11.2 & 272 & 22.3 & 334 & 27.4 & 358 & 29.4 & 3.55 \\
\hline $\begin{array}{l}\text { 6. Kitaptaki } \\
\text { etkinliklerle yetinir, } \\
\text { yenilerini } \\
\text { oluşturmam. }\end{array}$ & 653 & 53.6 & 305 & 25.0 & 140 & 11.5 & 79 & 6.5 & 42 & 3.4 & 4.19 \\
\hline $\begin{array}{l}\text { 7. Konu anlatırken } \\
\text { bazı noktaları eksik } \\
\text { bırakıp öğrencilerin } \\
\text { bulmasını sağlarım. }\end{array}$ & 87 & 7.1 & 108 & 8.9 & 340 & 27.9 & 346 & 28.4 & 338 & 27.7 & 3.61 \\
\hline
\end{tabular}

Tablo 4'de görüldüğü gibi, Sosyal Bilgiler öğretmen adaylarının yansıtıcı düşünme eğilimi ölçeğinin sürekli ve amaçlı düşünme alt boyutu incelendiğinde, en yüksek puan ortalamasının olduğu madde "Öğrencilerimin görüşlerine değer vermem $(\overline{\mathrm{X}}=4.63)$ " iken en düşük puan ortalamasının olduğu madde ise "Sınıfta tartışmayı teşvik eder yönetirim $(\overline{\mathrm{X}}=3.55)$ " şeklinde gerçekleşmiş̧ir. 
Tablo 5. Sosyal Bilgiler Öğretmen Adaylarını YANDE Ölçeği Açık Fikirlilik Alt Boyutuna Ait Görüşleri

\begin{tabular}{|c|c|c|c|c|c|c|c|c|c|c|c|}
\hline \multirow{2}{*}{ Maddeler } & \multicolumn{2}{|c|}{$\begin{array}{c}\text { Hiç } \\
\text { Katılmıyorum }\end{array}$} & \multicolumn{2}{|c|}{$\begin{array}{l}\text { Çoğunlukla } \\
\text { Katılmıyorum }\end{array}$} & \multicolumn{2}{|c|}{$\begin{array}{c}\text { Kismen } \\
\text { Kat1liyorum }\end{array}$} & \multicolumn{2}{|c|}{$\begin{array}{l}\text { Çoğunlukla } \\
\text { Katılıyorum }\end{array}$} & \multicolumn{2}{|c|}{$\begin{array}{l}\text { Tamamen } \\
\text { Katıliyorum }\end{array}$} & \multirow[t]{2}{*}{$\bar{x}$} \\
\hline & f & $\%$ & f & $\%$ & f & $\%$ & f & $\%$ & f & $\%$ & \\
\hline $\begin{array}{l}\text { 8. Öğretim } \\
\text { kazanımlarını (hedef- } \\
\text { davranışları) gözden } \\
\text { geçirmem. }\end{array}$ & 798 & 65.5 & 225 & 18.5 & 72 & 5.9 & 77 & 6.3 & 47 & 3.9 & 4.35 \\
\hline $\begin{array}{l}\text { 9. Öğretim } \\
\text { uygulamalarıyla ilgili } \\
\text { soru, tepki ve önerilere } \\
\text { açık değilim. }\end{array}$ & 841 & 69.0 & 203 & 16.7 & 84 & 6.9 & 58 & 4.8 & 33 & 2.7 & 4.44 \\
\hline $\begin{array}{l}\text { 10. Öğretme-öğrenme } \\
\text { sürecindeki olaylara çok } \\
\text { yönlü bakamam. }\end{array}$ & 745 & 61.1 & 283 & 23.2 & 99 & 8.1 & 48 & 3.9 & 44 & 3.6 & 4.34 \\
\hline $\begin{array}{l}\text { 11. Öğrencilerimin } \\
\text { bireysel } \\
\text { gereksinimlerinden } \\
\text { sorumlu değilim. }\end{array}$ & 787 & 64.6 & 223 & 18.3 & 126 & 10.3 & 39 & 3.2 & 44 & 3.6 & 4.37 \\
\hline $\begin{array}{l}\text { 12. Öğrencilerimin } \\
\text { eğitsel etkinliklerine } \\
\text { önem vermem. }\end{array}$ & 900 & 73.8 & 194 & 15.9 & 50 & 4.1 & 37 & 3.0 & 38 & 3.1 & 4.54 \\
\hline $\begin{array}{l}\text { 13. Öğrencilerimin } \\
\text { duygusal (duyuşsal) } \\
\text { davranışlarından } \\
\text { sorumlu değilim. }\end{array}$ & 794 & 65.1 & 235 & 19.3 & 118 & 9.7 & 30 & 2.5 & 42 & 3.4 & 4.40 \\
\hline
\end{tabular}

Tablo 5’te görüldüğü gibi, Sosyal Bilgiler öğretmen adaylarının yansıtıcı düşünme eğilimi ölçeğinin açık fikirlilik alt boyutu incelendiğinde, en yüksek puan ortalamasınun olduğu madde "Öğrencilerimin eğitsel etkinliklerine önem vermem" $(\overline{\mathrm{X}}=4.54)$ iken en düşük puan ortalamasının olduğu madde ise "Öğretim kazanımlarını (hedef-davranışları) gözden geçirmem" ( $\overline{\mathrm{X}}=4.35)$ şeklinde gerçekleşmiştir.

Tablo 6. Sosyal Bilgiler Öğretmen Adaylarının YANDE Ölçeği Sorgulayıcı ve Etkili Öğretim Alt Boyutuna Ait Görüşleri

\begin{tabular}{|c|c|c|c|c|c|c|c|c|c|c|c|}
\hline \multirow{2}{*}{ Maddeler } & \multicolumn{2}{|c|}{$\begin{array}{c}\text { Hiç } \\
\text { Katılmıyorum }\end{array}$} & \multicolumn{2}{|c|}{$\begin{array}{l}\text { Çoğunlukla } \\
\text { Katılmıyorum }\end{array}$} & \multicolumn{2}{|c|}{$\begin{array}{c}\text { Kismen } \\
\text { Katıliyorum }\end{array}$} & \multicolumn{2}{|c|}{$\begin{array}{l}\text { Çoğunlukla } \\
\text { Katılıyorum }\end{array}$} & \multicolumn{2}{|c|}{$\begin{array}{l}\text { Tamamen } \\
\text { Katıliyorum }\end{array}$} & \multirow[t]{2}{*}{$\bar{x}$} \\
\hline & f & $\%$ & f & $\%$ & f & $\%$ & f & $\%$ & f & $\%$ & \\
\hline $\begin{array}{l}\text { 14. Yeni materyalleri ve } \\
\text { etkinlikleri tanitmam. }\end{array}$ & 886 & 72.7 & 205 & 16.8 & 59 & 4.8 & 31 & 2.5 & 38 & 3.1 & 4.53 \\
\hline $\begin{array}{l}\text { 15. Dersin teorik } \\
\text { kısımlarını kavram } \\
\text { haritasıyla anlatmam. }\end{array}$ & 740 & 60.7 & 253 & 20.8 & 145 & 11.9 & 49 & 4.0 & 32 & 2.6 & 4.33 \\
\hline $\begin{array}{l}\text { 16. Öğrencilerin } \\
\text { hayallerine değer } \\
\text { vermem. }\end{array}$ & 1004 & 82.4 & 215 & 17.6 & - & - & - & - & - & - & 4.82 \\
\hline $\begin{array}{l}\text { 17. İşbirliği ile } \\
\text { öğrenmeye önem } \\
\text { vermem. }\end{array}$ & 875 & 71.8 & 217 & 17.8 & 73 & 6.0 & 30 & 2.5 & 24 & 2.0 & 4.55 \\
\hline $\begin{array}{l}\text { 18. Eleştirel bakış } \\
\text { açısına sahip değilim. }\end{array}$ & 802 & 65.8 & 225 & 18.5 & 106 & 8.7 & 53 & 4.3 & 33 & 2.7 & 4.40 \\
\hline
\end{tabular}


Tablo 6'da görüldüğü gibi, Sosyal Bilgiler öğretmen adaylarının yansıtıcı düşünme eğilimi ölçeğinin sorgulayıcı ve etkili öğretim alt boyutu incelendiğinde, en yüksek puan ortalamasınun olduğu madde "Öğrencilerin hayallerine değer vermem" $(\overline{\mathrm{X}}=4.82)$ iken en düşük puan ortalamasının olduğu madde ise "Dersin teorik kisımlarını kavram haritasıyla anlatmam" ( $\overline{\mathrm{X}}=$ 4.33) şeklinde gerçekleşmiştir.

Tablo 7. Sosyal Bilgiler Öğretmen Adaylarının YANDE Ölçeği Öğretim Sorumluluğu ve Bilimsellik Alt Boyutuna Ait Görüşleri

\begin{tabular}{|c|c|c|c|c|c|c|c|c|c|c|c|}
\hline \multirow{2}{*}{ Maddeler } & \multicolumn{2}{|c|}{$\begin{array}{c}\text { Hiç } \\
\text { Katılmıyorum }\end{array}$} & \multicolumn{2}{|c|}{$\begin{array}{l}\text { Çoğunlukla } \\
\text { Katılmıyorum }\end{array}$} & \multicolumn{2}{|c|}{$\begin{array}{c}\text { Kismen } \\
\text { Kat1liyorum }\end{array}$} & \multicolumn{2}{|c|}{$\begin{array}{l}\text { Çoğunlukla } \\
\text { Katılıyorum }\end{array}$} & \multicolumn{2}{|c|}{$\begin{array}{l}\text { Tamamen } \\
\text { Kat1liyorum }\end{array}$} & \multirow{2}{*}{$\bar{x}$} \\
\hline & f & $\%$ & f & $\%$ & f & $\%$ & f & $\%$ & f & $\%$ & \\
\hline $\begin{array}{l}\text { 19. Öğretimde kime, } \\
\text { neyi, ne zaman, niçin ve } \\
\text { nasıl yapacağımı } \\
\text { bilirim. }\end{array}$ & 99 & 8.1 & 100 & 8.2 & 187 & 15.3 & 414 & 34.0 & 419 & 34.4 & 3.78 \\
\hline $\begin{array}{l}\text { 20. Öğrencilerimle etkili } \\
\text { iletişsim kurmaya } \\
\text { çalışmam. }\end{array}$ & 847 & 69.5 & 176 & 14.4 & 61 & 5.0 & 60 & 4.9 & 75 & 6.2 & 4.36 \\
\hline $\begin{array}{l}\text { 21. Öğrencilerime } \\
\text { uygun öğrenme } \\
\text { materyali sunarım. }\end{array}$ & 88 & 7.2 & 102 & 8.4 & 97 & 8.0 & 331 & 27.2 & 601 & 49.3 & 4.03 \\
\hline $\begin{array}{l}\text { 22. Öğrencilerin } \\
\text { beklentilerini dikkate } \\
\text { almam. }\end{array}$ & 869 & 71.3 & 180 & 14.8 & 63 & 5.2 & 66 & 5.4 & 41 & 3.4 & 4.45 \\
\hline $\begin{array}{l}\text { 23. Yeni bir konuyu } \\
\text { ustaca tanıtır ve } \\
\text { anlatırım. }\end{array}$ & 61 & 5.0 & 108 & 8.9 & 211 & 17.3 & 410 & 33.6 & 429 & 35.2 & 3.85 \\
\hline
\end{tabular}

Tablo 7'de görüldüğü gibi, Sosyal Bilgiler öğretmen adaylarının yansıtıcı düşünme eğilimi ölçeğinin öğretim sorumluluğu ve bilimsellik alt boyutu incelendiğinde, en yüksek puan ortalamasınun olduğu madde "Öğrencilerin beklentilerini dikkate almam" ( $\overline{\mathrm{X}}=4.45)$ iken en düşük puan ortalamasının olduğu madde ise "Öğretimde kime, neyi, ne zaman, niçin ve nasıl yapacă̆ımı bilirim" ( $\overline{\mathrm{X}}=3.78)$ şeklinde gerçekleşmiştir.

Tablo 8. Sosyal Bilgiler Öğretmen Adaylarının YANDE Ölçeği Araştırmacı Alt Boyutuna Ait Görüşleri

\begin{tabular}{|c|c|c|c|c|c|c|c|c|c|c|c|}
\hline \multirow{2}{*}{ Maddeler } & \multicolumn{2}{|c|}{$\begin{array}{c}\text { Hiç } \\
\text { Katılmıyorum }\end{array}$} & \multicolumn{2}{|c|}{$\begin{array}{l}\text { Çoğunlukla } \\
\text { Katılmıyorum }\end{array}$} & \multicolumn{2}{|c|}{$\begin{array}{c}\text { Kismen } \\
\text { Kat1liyorum }\end{array}$} & \multicolumn{2}{|c|}{$\begin{array}{l}\text { Çoğunlukla } \\
\text { Katılıyorum }\end{array}$} & \multicolumn{2}{|c|}{$\begin{array}{l}\text { Tamamen } \\
\text { Kat1liyorum }\end{array}$} & \multirow[b]{2}{*}{$\bar{x}$} \\
\hline & f & $\%$ & f & $\%$ & f & $\%$ & f & $\%$ & f & $\%$ & \\
\hline $\begin{array}{l}\text { 24. Öğretim ortamına } \\
\text { ilişkin yaptığım } \\
\text { değişikliklerin } \\
\text { sonuçlarını düşünürüm. }\end{array}$ & 39 & 3.2 & 84 & 6.9 & 136 & 11.2 & 409 & 33.6 & 551 & 45.2 & 4.11 \\
\hline $\begin{array}{l}\text { 25. Öğretime ilişkin } \\
\text { problemleri algılar, } \\
\text { tanımlar, geneller ve } \\
\text { mesleki anlayışlarımı } \\
\text { değiştirmek ve } \\
\text { geliştirmek için } \\
\text { kullanırım. }\end{array}$ & 59 & 4.8 & 72 & 5.9 & 151 & 12.4 & 391 & 32.1 & 546 & 44.8 & 4.06 \\
\hline $\begin{array}{l}\text { 26. Araştırma ruhuna } \\
\text { sahip değilim. }\end{array}$ & 663 & 54.4 & 285 & 23.4 & 127 & 10.4 & 74 & 6.1 & 70 & 5.7 & 4.15 \\
\hline $\begin{array}{l}\text { 27.Öğretimimi objektif } \\
\text { bir şekilde } \\
\text { değerlendirebilirim. }\end{array}$ & 88 & 7.2 & 85 & 7.0 & 163 & 13.4 & 369 & 30.3 & 514 & 42.2 & 3.93 \\
\hline
\end{tabular}




\begin{tabular}{|l|c|c|c|c|c|c|c|c|c|c|c|}
\hline $\begin{array}{l}\text { 28. Öğgretmen olarak } \\
\text { kendimi geliştirmeye } \\
\text { açı değilim. }\end{array}$ & 806 & 66.1 & 194 & 15.9 & 83 & 6.8 & 76 & 6.2 & 60 & 4.9 & 4.32 \\
\hline $\begin{array}{l}\text { 29. Öğretme sanatının } \\
\text { iyi yönleriyle ilgilenirim }\end{array}$ & 76 & 6.2 & 88 & 7.2 & 187 & 15.3 & 354 & 29.0 & 514 & 42.2 & 3.94 \\
\hline
\end{tabular}

Tablo 8'de görüldüğg̈ gibi, Sosyal Bilgiler öğretmen adaylarının yansıtıcı düşünme eğilimi ölçeğinin araştırmacı alt boyutu incelendiğinde, en yüksek puan ortalamasınun olduğu madde "Öğretmen olarak kendimi geliştirmeye açık değilim" ( $\overline{\mathrm{X}}=4.32)$ iken en düşük puan ortalamasının olduğu madde ise "Öğretimimi objektif bir şekilde değerlendirebilirim" $(\overline{\mathrm{X}}=$ 3.93) şeklinde gerçekleşmiştir.

Tablo 9. Sosyal Bilgiler Öğretmen Adaylarının YANDE Ölçeği Öngörülü ve İçtem Olma Alt Boyutuna Ait Görüşleri

\begin{tabular}{|c|c|c|c|c|c|c|c|c|c|c|c|}
\hline \multirow{2}{*}{ Maddeler } & \multicolumn{2}{|c|}{$\begin{array}{c}\text { Hiç } \\
\text { Katılmıyorum }\end{array}$} & \multicolumn{2}{|c|}{$\begin{array}{l}\text { Çoğunlukla } \\
\text { Katılmıyorum }\end{array}$} & \multicolumn{2}{|c|}{$\begin{array}{c}\text { Kismen } \\
\text { Kat1liyorum }\end{array}$} & \multicolumn{2}{|c|}{$\begin{array}{l}\text { Çoğunlukla } \\
\text { Katılıyorum }\end{array}$} & \multicolumn{2}{|c|}{$\begin{array}{l}\text { Tamamen } \\
\text { Katıliyorum }\end{array}$} & \multirow[b]{2}{*}{$\bar{x}$} \\
\hline & f & $\%$ & f & $\%$ & f & $\%$ & f & $\%$ & f & $\%$ & \\
\hline $\begin{array}{l}\text { 30. Öğrencilerimin } \\
\text { (sınıfın ötesini) geleceği } \\
\text { görmesine yardımc1 } \\
\text { olurum. }\end{array}$ & 64 & 5.3 & 90 & 7.4 & 106 & 8.7 & 356 & 29.2 & 603 & 49.5 & 4.10 \\
\hline $\begin{array}{l}\text { 32. Öğretim } \\
\text { uygulamalarımla ilgili } \\
\text { diğer arkadaşlarımla } \\
\text { görüş alış verişinde } \\
\text { bulunurum. }\end{array}$ & 41 & 3.4 & 93 & 7.6 & 100 & 8.2 & 356 & 29.2 & 629 & 51.6 & 4.18 \\
\hline $\begin{array}{l}\text { 33. Kendimi } \\
\text { öğrencilerimin yerine } \\
\text { koyup düşünebilirim. }\end{array}$ & 34 & 2.8 & 72 & 5.9 & 146 & 12.0 & 340 & 27.9 & 627 & 51.4 & 4.19 \\
\hline $\begin{array}{l}\text { 35.Öğretimimle ilgili } \\
\text { diğer öğretmenlerin } \\
\text { eleştirilerinden yapıcı } \\
\text { bir şekilde yararlanırım. }\end{array}$ & 49 & 4.0 & 44 & 3.6 & 159 & 13.0 & 350 & 28.7 & 617 & 50.6 & 4.18 \\
\hline
\end{tabular}

Tablo 9'da görüldüğü gibi, Sosyal Bilgiler öğretmen adaylarının yansıtıcı düşünme eğilimi ölçeğinin öngörülü ve içtem olma alt boyutu incelendiğinde, en yüksek puan ortalamasınun olduğu madde "Kendimi öğrencilerimin yerine koyup düşünebilirim" $(\overline{\mathrm{X}}=4.19)$ iken en düşük puan ortalamasının olduğu madde ise "Öğrencilerimin (sinıfin ötesini) geleceği görmesine yardımcı olurum" ( $\overline{\mathrm{X}}=4.10)$ şeklinde gerçekleşmiştir.

Tablo 10. Sosyal Bilgiler Öğretmen Adaylarının YANDE Ölçeği Mesleğe Bakış Alt Boyutuna Ait Görüşleri

\begin{tabular}{|c|c|c|c|c|c|c|c|c|c|c|c|}
\hline \multirow{2}{*}{ Maddeler } & \multicolumn{2}{|c|}{$\begin{array}{l}\text { Hiç } \\
\text { Katılmıyorum }\end{array}$} & \multicolumn{2}{|c|}{$\begin{array}{l}\text { Çoğunlukla } \\
\text { Katılmıyorum }\end{array}$} & \multicolumn{2}{|c|}{$\begin{array}{l}\text { Kismen } \\
\text { Katıliyorum }\end{array}$} & \multicolumn{2}{|c|}{$\begin{array}{l}\text { Çoğunlukla } \\
\text { Katılıyorum }\end{array}$} & \multicolumn{2}{|c|}{$\begin{array}{l}\text { Tamamen } \\
\text { Katıliyorum }\end{array}$} & \multirow[t]{2}{*}{$\bar{x}$} \\
\hline & f & $\%$ & f & $\%$ & $\mathbf{F}$ & $\%$ & f & $\%$ & f & $\%$ & \\
\hline $\begin{array}{l}\text { 31. Öğretmen olarak } \\
\text { kendimi değerlendir- } \\
\text { mede dürüst değilim. }\end{array}$ & 737 & 60.5 & 244 & 20.0 & 111 & 9.1 & 72 & 5.9 & 55 & 4.5 & 4.26 \\
\hline $\begin{array}{l}\text { 34. Öğretmenliği } \\
\text { sevmiyorum. }\end{array}$ & 823 & 67.5 & 157 & 12.9 & 106 & 8.7 & 65 & 5.3 & 68 & 5.6 & 4.31 \\
\hline
\end{tabular}

Tablo 10'da görüldüğü gibi, Sosyal Bilgiler öğretmen adaylarının yansıtıcı düşünme eğilimi 
ölçeğinin öngörülü ve içtem olma alt boyutu incelendiğinde, en yüksek puan ortalamasının olduğu madde "Öğretmenliği sevmiyorum" ( $\overline{\mathrm{X}}=4.31)$ iken en düşük puan ortalamasının olduğu madde ise "Öğretmen olarak kendimi değerlendirmede dürüst değilim" ( $\overline{\mathrm{X}}=4.26)$ şeklinde gerçekleşmiştir.

Tablo 11. YANDE Ölçeğinde Bulunan Faktörler Arası Korelasyon Kat Sayıları

\begin{tabular}{|c|c|c|c|c|c|c|c|}
\hline $\begin{array}{l}\text { Faktör } \\
(\mathrm{N}=1219)\end{array}$ & 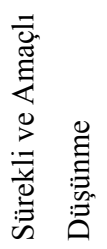 & 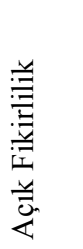 & 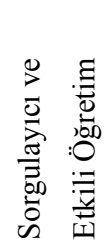 & 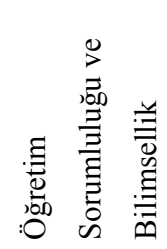 & 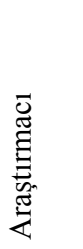 & 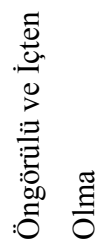 & 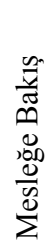 \\
\hline Sürekli ve Amaçlı Düşünme & 1 & & & & & & \\
\hline Açık Fikirlilik & $.074^{*}$ & 1 & & & & & \\
\hline Sorgulayıcı ve Etkili Öğretim & .013 & $.733^{*}$ & 1 & & & & \\
\hline Öğretim Sorumluluğu ve Bilimsellik & $.248^{*}$ & $.155^{*}$ & .050 & 1 & & & \\
\hline Araştırmac1 & $.226^{*}$ & $.194^{*}$ & $.187^{*}$ & $.391^{*}$ & 1 & & \\
\hline Öngörülü ve İçten Olma & $.188^{*}$ & $.479^{*}$ & $.487^{*}$ & $.288^{*}$ & $.450^{*}$ & 1 & \\
\hline Mesleğe Bakış & .013 & $.469^{*}$ & $.549^{*}$ & $.141^{*}$ & $.160^{*}$ & $.519^{*}$ & 1 \\
\hline
\end{tabular}

$\mathrm{p}<0.01$

Faktörler arasındaki korelasyonlar, katılımcıların $(\mathrm{N}=1219)$ verdikleri cevaplara göre analiz edilmiştir. En yüksek korelasyon, "sorgulayıcı ve etkili öğretim" ile "açık fikirlilik" arasında bulunan 0.733 'lük bir ilişkidir. En düşük korelasyon ise "öngörülü ve içten olma" ile "araştırmacı" arasında olan 0.450'lik bir ilişki olduğu görülmektedir. Orta seviyede korelasyon için de "mesleğe baklş" ile "sorgulayıcı ve etkili öğretim" arasında olup, 0.549 'luk bir ilişki mevcuttur. Buradaki korelâsyonların 0.01 düzeyinde pozitif yönde manidar olduğu görülmektedir.

3. 2. Sosyal Bilgiler öğretmen adaylarının $Y A N D E$ Ölçeğine göre yansıtıcı düşünme eğilimleri cinsiyet, aile gelir durumu ve mezun olunan lise değişkenlerine göre farklılık göstermekte midir?

Tablo 12. Öğretmen Adaylarının Yansıtıcı Düşünme Eğilimi Ölçeği’nden Aldıkları Puanların Cinsiyete Göre Farklılığı İçin Mann Whitney U-Testi Sonuçları

\begin{tabular}{|c|c|c|c|c|c|c|}
\hline $\begin{array}{l}\text { YANDE } \\
\text { Ölçeğinin Boyutları }\end{array}$ & Grup & $\mathbf{N}$ & $\begin{array}{l}\text { Sira } \\
\text { Ortalaması }\end{array}$ & $\begin{array}{l}\text { Sira } \\
\text { Toplamı }\end{array}$ & $\mathbf{U}$ & $\mathbf{p}$ \\
\hline \multirow{2}{*}{ Sürekli ve Amaçlı Düşünme } & $\mathrm{K} 1 \mathrm{z}$ & 607 & 601.06 & 364843.5 & \multirow{2}{*}{180315.5} & \multirow{2}{*}{.376} \\
\hline & Erkek & 612 & 618.87 & 378746.5 & & \\
\hline \multirow{2}{*}{ Açık Fikirlilik } & K1z & 607 & 594.32 & 360749.5 & \multirow{2}{*}{176221.5} & \multirow{2}{*}{.112} \\
\hline & Erkek & 612 & 625.56 & 382840.5 & & \\
\hline \multirow{2}{*}{ Sorgulayıcı ve Etkili Öğretim } & $\mathrm{K} 1 \mathrm{z}$ & 607 & 600.45 & 364475.0 & \multirow{2}{*}{179947.0} & \multirow{2}{*}{.330} \\
\hline & Erkek & 612 & 619.47 & 379115.0 & & \\
\hline \multirow{2}{*}{ Öğrt. Sorumluluğu ve Bilimsellik } & $\mathrm{K} 1 \mathrm{z}$ & 607 & 601.15 & 364898.0 & \multirow{2}{*}{180370.0} & \multirow{2}{*}{.377} \\
\hline & Erkek & 612 & 618.78 & 378692.0 & & \\
\hline \multirow{2}{*}{ Araştırmacı } & $\mathrm{K} 1 \mathrm{z}$ & 607 & 604.91 & 367178.0 & \multirow{2}{*}{182650.0} & \multirow{2}{*}{.611} \\
\hline & Erkek & 612 & 615.05 & 376412.0 & & \\
\hline \multirow{2}{*}{ Öngörülü ve İçten Olma } & $\mathrm{K} 1 \mathrm{z}$ & 607 & 615.31 & 373495.0 & \multirow{2}{*}{182517.0} & \multirow{2}{*}{.594} \\
\hline & Erkek & 612 & 604.73 & 370095.0 & & \\
\hline
\end{tabular}




\begin{tabular}{|l|c|c|c|c|c|c|}
\hline \multirow{2}{*}{ Mesleğe Bakış } & Kız & 607 & 596.44 & 362040.5 & \multirow{2}{*}{177512.5} & .150 \\
\cline { 1 - 7 } & Erkek & 612 & 623.45 & 381549.5 & & \multirow{2}{*}{.013} \\
\hline \multirow{2}{*}{ YANDE Ölçeği Toplam Puan } & Kız & 607 & 584.80 & 354976.5 & \multirow{2}{*}{170448.5} & .013 \\
\cline { 1 - 8 } & Erkek & 612 & 634.99 & 388613.5 & & \\
\hline
\end{tabular}

Tablo 12'de Sosyal Bilgiler öğretmen adaylarının "Yansıtıcı Düşünme Eğilimi” (YANDE) ölçeği puanlarının cinsiyet türüne göre karşılaştırılmasına ilişkin Mann Whitney U-Testi sonuçları incelenmiștir. Buna göre, $Y A N D E$ ölçeğindeki, sürekli ve amaçlı düşünme, açık fikirlilik, sorgulayıc1 ve etkili öğretim, öğretme sorumluluğu ve bilimsellik, araştırmacı, öngörülü ve içten olma ve mesleğe bakış alt boyutlarına yönelik görüşlerinin cinsiyete göre anlamlı farklılık göstermediği; toplam puana göre ise anlamlı farklılık gösterdiği belirlenmiştir [U=170448.5; $\mathrm{p}<.05]$. Çalışma grubundaki Sosyal Bilgiler kız öğretmen adaylarının yansıtıcı düşünme eğilimi ölçeğinden almış oldukları toplam puanlarının sıra ortalaması (584.80) iken, bu değer Sosyal Bilgiler erkek öğretmen adaylarında (634.99) olarak gerçekleşmiştir. (1) ve (2) Sosyal Bilgiler öğretmen adaylarının yansıtıcı düşünme eğilimi ölçeğinin alt boyutlarına ait görüşleri benzerlik gösterirken, toplamında ise erkek lehine anlamlı bir farklılı̆̆ın olduğu görülmektedir.

Tablo 13. Öğretmen Adaylarının Yansıtıcı Düşünme Eğilimi Ölçeği’nden Aldıkları Puanların Aile Gelirlerine Göre Farklılığı İçin Kruskal-Wallis Testi Sonuçları

\begin{tabular}{|c|c|c|c|c|c|c|}
\hline $\begin{array}{l}\text { YANDE } \\
\text { Ölçeğinin Boyutları }\end{array}$ & Grup & $\mathbf{N}$ & $\begin{array}{l}\text { Sira } \\
\text { Ortalamasi }\end{array}$ & sd & $\chi^{2}$ & $\mathbf{p}$ \\
\hline \multirow{4}{*}{ Sürekli ve Amaçlı Düşünme } & 700 & 299 & 621.38 & \multirow{4}{*}{3} & \multirow{4}{*}{13.73} & \multirow{4}{*}{.003} \\
\hline & $701-1500$ & 541 & 601.11 & & & \\
\hline & $1501-2500$ & 294 & 578.69 & & & \\
\hline & 2501 ve üstü & 85 & 734.85 & & & \\
\hline \multirow{4}{*}{ Açık Fikirlilik } & 700 & 299 & 630.41 & \multirow{4}{*}{3} & \multirow{4}{*}{12.89} & \multirow{4}{*}{.005} \\
\hline & $701-1500$ & 541 & 588.64 & & & \\
\hline & $1501-2500$ & 294 & 652.99 & & & \\
\hline & 2501 ve üstü & 85 & 525.47 & & & \\
\hline \multirow{4}{*}{ Sorgulayıcı ve Etkili Öğretim } & 700 & 299 & 614.65 & \multirow{4}{*}{3} & \multirow{4}{*}{1.75} & \multirow{4}{*}{.626} \\
\hline & $701-1500$ & 541 & 601.38 & & & \\
\hline & $1501-2500$ & 294 & 628.53 & & & \\
\hline & 2501 ve üstü & 85 & 584.38 & & & \\
\hline \multirow{4}{*}{ Öğrt. Sorumluluğu ve Bilimsellik } & 700 & 299 & 606.92 & \multirow{4}{*}{3} & \multirow{4}{*}{.19} & \multirow{4}{*}{.979} \\
\hline & $701-1500$ & 541 & 607.21 & & & \\
\hline & $1501-2500$ & 294 & 617.14 & & & \\
\hline & 2501 ve üstü & 85 & 613.88 & & & \\
\hline \multirow{4}{*}{ Araştırmacı } & 700 & 299 & 581.56 & \multirow{4}{*}{3} & \multirow{4}{*}{3.72} & \multirow{4}{*}{.293} \\
\hline & $701-1500$ & 541 & 618.23 & & & \\
\hline & $1501-2500$ & 294 & 610.80 & & & \\
\hline & 2501 ve üstü & 85 & 654.89 & & & \\
\hline \multirow{4}{*}{ Öngörülü ve İçten Olma } & 700 & 299 & 586.58 & \multirow{4}{*}{3} & \multirow{4}{*}{5.79} & \multirow{4}{*}{.122} \\
\hline & $701-1500$ & 541 & 622.83 & & & \\
\hline & $1501-2500$ & 294 & 591.78 & & & \\
\hline & 2501 ve üstü & 85 & 673.74 & & & \\
\hline \multirow{4}{*}{ Mesleğe Bakış } & 700 & 299 & 626.47 & \multirow{4}{*}{3} & \multirow{4}{*}{9.21} & \multirow{4}{*}{.027} \\
\hline & $701-1500$ & 541 & 605.27 & & & \\
\hline & $1501-2500$ & 294 & 629.66 & & & \\
\hline & 2501 ve üstü & 85 & 514.14 & & & \\
\hline \multirow{4}{*}{ YANDE Ölçeği Toplam Puan } & 700 & 299 & 609.91 & & & \\
\hline & $701-1500$ & 541 & 592.19 & & & \\
\hline & $1501-2500$ & 294 & 629.80 & 3 & 3.71 & .293 \\
\hline & 2501 ve üstü & 85 & 655.18 & & & \\
\hline
\end{tabular}


Tablo 13'de Sosyal Bilgiler öğretmen adaylarının "Yansitıcı Düşünme Eğilimi” (YANDE) Ölçeği puanlarının aile gelir durumuna göre karşılaştırılmasına ilişkin Kruskall Wallis Testi sonuçları incelenmiştir. Buna göre, YANDE ölçeğindeki, sorgulayıcı ve etkili öğretim, öğretme sorumluluğu ve bilimsellik, araştırmacı, öngörülü ve içten olma alt boyutları ile toplam puana yönelik görüşlerinin aile gelirlerine göre anlamlı farklılık göstermediği; sürekli ve amaçlı düşünme, açık fikirlilik ve mesleğe bakış alt boyutlarında ise anlamlı farklılık gösterdiği belirlenmiştir $\left[\chi^{2}=13.73 ; \chi^{2}=12.89 ; \chi^{2}=9.21 ; p<.05\right]$. Yansıtıcı düşünme eğilimi ölçeğinde yer alan sürekli ve amaçlı düşünme alt boyutunda aile gelir durumundaki grupların sıra ortalamaları dikkate alındığında en yüksek (2501 ve üstü) olduğu, onu da sirasıyla (700), (701-1500) ve (1501-2500) ün takip ettiği; açık fikirlilik alt boyutunda aile gelir durumundaki grupların sıra ortalamaları dikkate alındığında en yüksek (1501-2500) olduğu, onu da sirasıyla (700), (701$1500)$ ve (2500 ve üstü) ün takip ettiği; mesleğe bakış alt boyutunda aile gelir durumundaki grupların sıra ortalamaları dikkate alındığında en yüksek (1501-2500) olduğu, onu da sirasıyla (700), (701-1500) ve (2500 ve üstü) ün takip ederek sıralandığı görülmektedir.

Kruskal Wallis H Test sonuçlarında görülen anlamlı farklılığın kaynağını belirleyebilmek için gruplar arasında Mann Whitney U Testi yapılmıştır. Analiz sonuçlarına göre aile gelir durumunun yansitıcı düşünme eğilimi ölçeği alt boyutlarından olan sürekli ve amaçlı düşünme boyutunda (700)-(2500 ve üstü) arasında ( $\mathrm{p}=.008)$ (2500 ve üstü) lehine ve (701-1500)-(2500 ve üstü) arasında ( $\mathrm{p}=.001)$ (2500 ve üstü) lehine; açık fikirlilik alt boyutunda (700)-(2500 ve üstü) arasinda $(\mathrm{p}=.013)(700)$ lehine ve $(701-1500)-(1501-2500)$ arasinda $(\mathrm{p}=.009)(1501-2500)$ lehine; mesleğe bakış alt boyutunda (700)-(2500 ve üstü) arasında $(\mathrm{p}=.006)(700)$ lehine ve (701-1500)-(2500 ve üstü) arasında $(\mathrm{p}=.016)(701-1500)$ lehine anlamlı bir fark bulunmaktadır.

Tablo 14. Öğretmen Adaylarının Yansıtıcı Düşünme Eğilimi Ölçeği’nden Aldıkları Puanların Mezun Oldukları Lise Türüne Göre Farklılığı İçin Kruskal-Wallis Testi Sonuçları

\begin{tabular}{|c|c|c|c|c|c|c|}
\hline $\begin{array}{l}Y A N D E \\
\text { Ölçeğinin Boyutları }\end{array}$ & Grup & $\mathbf{N}$ & $\begin{array}{l}\text { Sira } \\
\text { Ortalamasi }\end{array}$ & sd & $\chi^{2}$ & $\mathbf{p}$ \\
\hline \multirow{5}{*}{ Sürekli ve Amaçlı Düşünme } & Düz Lise & 1120 & 608.79 & \multirow{5}{*}{4} & \multirow{5}{*}{35.37} & \multirow{5}{*}{.00} \\
\hline & Fen Lisesi & 18 & 718.25 & & & \\
\hline & Sos.Bil.Lis & 30 & 640.35 & & & \\
\hline & Mes.Lis. & 37 & 406.51 & & & \\
\hline & Diğer Lis. & 14 & 1040.39 & & & \\
\hline \multirow{5}{*}{ Açık Fikirlilik } & Düz Lise & 1120 & 607.99 & \multirow{5}{*}{4} & \multirow{5}{*}{3.03} & \multirow{5}{*}{.55} \\
\hline & Fen Lisesi & 18 & 675.39 & & & \\
\hline & Sos.Bil.Lis & 30 & 551.53 & & & \\
\hline & Mes.Lis. & 37 & 676.70 & & & \\
\hline & Diğer Lis. & 14 & 635.50 & & & \\
\hline \multirow{5}{*}{ Sorgulayıcı ve Etkili Öğretim } & Düz Lise & 1120 & 606.40 & \multirow{5}{*}{4} & \multirow{5}{*}{3.08} & \multirow{5}{*}{.54} \\
\hline & Fen Lisesi & 18 & 647.75 & & & \\
\hline & Sos.Bil.Lis & 30 & 628.93 & & & \\
\hline & Mes.Lis. & 37 & 630.69 & & & \\
\hline & Diğer Lis. & 14 & 754.32 & & & \\
\hline \multirow{5}{*}{ Öğrt. Sorumluluğu ve Bilimsellik } & Düz Lise & 1120 & 613.80 & \multirow{5}{*}{4} & \multirow{5}{*}{5.93} & \multirow{5}{*}{.20} \\
\hline & Fen Lisesi & 18 & 673.08 & & & \\
\hline & Sos.Bil.Lis & 30 & 618.97 & & & \\
\hline & Mes.Lis. & 37 & 500.85 & & & \\
\hline & Diğer Lis. & 14 & 494.18 & & & \\
\hline \multirow{4}{*}{ Araştırmacı } & Düz Lise & 1120 & 611.19 & \multirow{4}{*}{4} & \multirow{4}{*}{2.43} & \multirow{4}{*}{.65} \\
\hline & Fen Lisesi & 18 & 501.42 & & & \\
\hline & Sos.Bil.Lis & 30 & 652.80 & & & \\
\hline & Mes.Lis. & 37 & 608.14 & & & \\
\hline
\end{tabular}




\begin{tabular}{|c|c|c|c|c|c|c|}
\hline & Diğer Lis. & 14 & 567.36 & & & \\
\hline \multirow{5}{*}{ Öngörülü ve İçten Olma } & Düz Lise & 1120 & 612.72 & \multirow{5}{*}{4} & \multirow{5}{*}{1.74} & \multirow{5}{*}{.78} \\
\hline & Fen Lisesi & 18 & 568.36 & & & \\
\hline & Sos.Bil.Lis & 30 & 621.05 & & & \\
\hline & Mes.Lis. & 37 & 573.51 & & & \\
\hline & Diğer Lis. & 14 & 518.50 & & & \\
\hline \multirow{5}{*}{ Mesleğe Bakış } & Düz Lise & 1120 & 612.93 & \multirow{5}{*}{4} & \multirow{5}{*}{1.73} & \multirow{5}{*}{.78} \\
\hline & Fen Lisesi & 18 & 555.17 & & & \\
\hline & Sos.Bil.Lis & 30 & 610.68 & & & \\
\hline & Mes.Lis. & 37 & 575.93 & & & \\
\hline & Diğer Lis. & 14 & 534.75 & & & \\
\hline \multirow{5}{*}{ YANDE Ölçeği Toplam Puan } & Düz Lise & 1120 & 610.06 & \multirow{5}{*}{4} & \multirow{5}{*}{8.54} & \multirow{5}{*}{.07} \\
\hline & Fen Lisesi & 18 & 663.19 & & & \\
\hline & Sos.Bil.Lis & 30 & 642.57 & & & \\
\hline & Mes.Lis. & 37 & 489.22 & & & \\
\hline & Diğger Lis. & 14 & 786.32 & & & \\
\hline
\end{tabular}

Tablo 14'de Sosyal Bilgiler öğretmen adaylarının "Yansıtıcı Düşünme Eğilimi” (YANDE) ölçeği puanlarının mezun oldukları lise türüne göre karşılaştırılmasına ilişkin Kruskall Wallis testi sonuçları incelenmiştir. Buna göre, YANDE Ölçeği'ndeki, açık fikirlilik, sorgulayıcı ve etkili öğretim, öğretme sorumluluğu ve bilimsellik, araştırmacı, öngörülü ve içten olma, mesleğe bakış alt boyutları ile toplam puana göre yönelik görüşlerinin aile gelirlerine göre anlamlı farklılık göstermediği; sürekli ve amaçlı düşünme alt boyutunda ise anlamlı farklılık gösterdiği belirlenmiştir $\left[\chi^{2}=35.37 ; \mathrm{p}<.05\right]$. Çalışma grubundaki Sosyal Bilgiler öğretmen adaylarının mezun oldukları lise türüne göre yansıtıcı düşünme eğilimi ölçeği boyutlarından olan sürekli ve amaçlı düşünme alt boyutunda anlamlı farkl1lık gösterdiği, grupların sıra ortalamaları dikkate alındığında en yüksek (Diğer Lise Mezunu) olduğu, onu da sırasıyla (Fen Lisesi Mezunu), (Sosyal Bilimler Lisesi Mezunu), (Düz Lise Mezunu) ve (Meslek Lisesi Mezunu) ün takip ederek sıralandığı görülmektedir.

Kruskal Wallis H Test sonuçlarında görülen anlamlı farklılığın kaynağını belirleyebilmek için gruplar arasında Mann Whitney U Testi yapılmıştır. Analiz sonuçlarına göre mezun oldukları lise türüne göre yansıtıcı düşünme eğilimi ölçeği alt boyutlarından olan sürekli ve amaçlı düşünme boyutunda (Düz Lise Mezunu)-(Meslek Lisesi) arasında ( $\mathrm{p}=.001)$ (Düz Lise Mezunu) lehine, (Fen Lisesi Mezunu)-(Meslek Lisesi Mezunu) arasinda ( $\mathrm{p}=.002)$ (Fen Lisesi Mezunu) lehine, (Sosyal Bilimler Mezunu)-(Meslek Lisesi Mezunu) arasında ( $\mathrm{p}=.003)$ (Sosyal Bilimler Lisesi Mezunu) lehine, (Düz Lise Mezunu)-(Diğer Lise Mezunu) arasında ( $\mathrm{p}=.000)$ (Diğer Lise Mezunu) lehine, (Fen Lisesi Mezunu)-(Diğer Lise Mezunu) arasında ( $\mathrm{p}=.001)$ (Diğer Lise Mezunu) lehine, (Sosyal Bilimler Lisesi Mezunu)-(Diğer Lise Mezunu) arasında $(p=.000)$ (Diğer Lise Mezunu) lehine ve (Meslek Lisesi Mezunu)-(Diğer Lise Mezunu) arasında ( $p=.000)$ (Diğer Lise Mezunu) anlamlı bir fark bulunmaktadır.

\section{Tartışma, Sonuç ve Öneriler}

Sosyal Bilgiler öğretmen adaylarının, yansıtıcı düşünme eğilimlerini belirlemek amacıyla yapılan bu araştırmada, öğretmen adaylarının, Yansıtıcı Düşünme Eğilimi (YANDE) Ölçeği'ne göre yansitıcı düşünme eğilimlerinin "orta düzeyde" olduğu görülmüştür. Sosyal Bilgiler öğretmen adaylarının $Y A N D E$ ölçeğinin alt boyutlarından aldıkları puanlara göre değerlendirildiğinde ise "sürekli ve amaçlı düşünme" alt boyutuna göre orta seviyede, "açık fikirlilik" alt boyutuna göre düşük seviyede, "sorgulayıcı ve etkili öğretim" alt boyutuna göre düşük seviyede, "öğretim sorumluluğu ve bilimsellik" alt boyutuna göre orta seviyede, "araştırmacı" alt boyutuna göre yüksek seviyede, "öngörülü ve içten olma" alt boyutuna göre yüksek seviyede ve "mesleğe bakış" alt boyutunda ise orta seviyede olduğu belirlenmiştir. Aydın ve Çelik (2013) ise, Güney 
(2008) tarafından geliştirilen yansıtıcı düşünme ölçeğini kullanarak yaptıkları çalışmalarında Sosyal Bilgiler öğretmen adaylarının yansıtıcı düşünme eğilimlerinin yüksek olduğunu ortaya koymuşlardır. Şahan ve Kalkay (2011) ise öğretmen adayları ile yaptıkları çalışmada Yansıtıcı Düşünme Eğilimi (YANDE) ölçeğine göre öğretmen adaylarının yansıtıcı düşünme eğilimlerinin düşük düzeyde olduğunu tespit etmişlerdir. Ayrıca öğretmenlerle yapılan çalışmalarda ise öğretmenlerin yansıtıcı düşünme düzeylerinin genel olarak yüksek olduğu görülmüştür (Dolapçığlu, 2007; Aslan, 2009; Duban, \& Yelken, 2010; Karadağ, 2010; Hasırc1, \& Sadık, 2011, Durdukoca, \& Demir, 2012). Araştırma sonuçları genel olarak değerlendirildiğinde, öğretmenlerin yansitıcı düşünce eğilimlerinin öğretmen adaylarına göre daha yüksek olduğu görülmektedir. Bu sonuca göre öğretmenlerin mesleğin içinde olmalarının onların yansıtıcı düşünce eğilimlerini olumlu etkilediği söylenebilir.

Çalışmada, YANDE Ölçeği'nin sürekli ve amaçlı düşünme, açık fikirlilik, sorgulayıcı ve etkili öğretim, öğretme sorumluluğu ve bilimsellik, araştırmacı, öngörülü ve içten olma ve mesleğe bakış alt boyutlarına göre Sosyal Bilgiler öğretmen adaylarının cinsiyet değişkenine göre görüşlerinin anlamlı farklılık göstermediği belirlenmiştir. Literatürde de Durdukoca ve Demir (2012), Özmen (2011), Şahin (2011), Karadağ (2010), Dolapçığlu (2007), İnönü (2006) gibi araştırmacılar çalışmalarında öğretmenlerin yansıtıcı öğretmen özelliklerine sahip olma düzeylerinde cinsiyetlerine göre genel olarak anlamlı bir farklılık göstermediği sonucuna ulaşmışlardır. Fakat kadın öğretmenlerin yansıtıcı düşünme eğilimlerinin erkek öğretmenlerden genel olarak daha yüksek olduğunu gösteren çalışmalar da mevcuttur (Aslan, 2009; Duban ve Yelken, 2010; Hasırcı ve Sadık, 2011; Aydın ve Çelik, 2013). Bu çalışmada ise YANDE Ölçeği'nin alt boyutlarına göre cinsiyet değişkeninde anlamlı fark olmamasına rağmen toplam puana göre çalışmaya katılan öğretmen adaylarının cinsiyetlerine göre puanlarının erkek öğretmen adayları lehine anlamlı farklılık gösterdiği belirlenmiştir.

Sosyal Bilgiler öğretmen adaylarının YANDE ölçeğindeki, açık fikirlilik, sorgulayıcı ve etkili öğretim, öğretme sorumluluğu ve bilimsellik, araştırmacı, öngörülü ve içten olma, mesleğe bakış alt boyutları ile toplam puana yönelik görüşlerinin aile gelirlerine göre anlamlı farklılık göstermediği, sadece sürekli ve amaçlı düşünme alt boyutunda anlamlı farklılığın olduğu belirlenmiştir. Öğrencilerin sıra ortalamaları dikkate alındığında bu farklılığın aile geliri yükssek olan öğrenciler lehine olduğu görülmektedir. Genel olarak değerlendirildiğinde ise araştırmanın aile geliri değişkenine yönelik sonuçlarının, Aydın ve Çelik'in (2013), aile sosyo-ekonomik düzeyinin Sosyal Bilgiler oğretmen adaylarının yansıtıcı düşünme eğilimlerine etkisi yoktur, bulgusuyla paralellik gösterdiği söylenebilir.

Çalı̧̧ma grubundaki Sosyal Bilgiler öğretmen adaylarının mezun oldukları lise türüne göre yansıtıcı düşünme eğilimi ölçeği boyutlarından olan sürekli ve amaçlı düşünme alt boyutunda anlamlı farklılık gösterdiği görülmektedir. Grupların sıra ortalamaları dikkate alındığında en yüksek düzeyde olan Anadolu Lisesi'dir. Onu da sırasıyla Fen Lisesi, Sosyal Bilimler Lisesi, Düz Lise ve Meslek Lisesi takip etmektedir. Norton (1997) araştırmasında, yansıtıcı düşünme ile etkili öğretim arasında olumlu ilişki olduğunu ifade etmiştir (akt. Tok, 2008). Bu doğrultuda lise eğitiminin yansıtıcı düşünmeyi etkilediği düşünülebilir. Ayrıca bu sonuç, lise türlerinin üniversiteye girişteki başarıları ile paralellik göstermektedir. Bu da, akademik başarıda lise türü değişkeninin etkili olduğunu desteklemektedir.

Araştırma sonuçları değerlendirildiğinde öncelikle yansıtıcı düşünce eğilimleri bakımından öğretmen adayları ile daha fazla çalışmaya ihtiyaç olduğu görülmektedir. Bu çalışmalarda özellikle cinsiyet değişkeni üzerinde daha fazla açıklayıcı sonuca ihityaç vardır. Ayrıca farklı yansıtıcı düşünce eğilimi belirleme ölçeklerine göre öğretmen adaylarının eğilimlerine bakmanın ve bu sonuçların nitel verilerle desteklenmesinin yararlı olacağı düşünülmektedir. Öğretmen adaylarının yansıtıcı düşünce eğilimlerini etkileyen unsurların belirlenmesi için YANDE ölçeğinin alt boyutları ile ilgili durum çalışmalarının da alana katkı sağlayacağına inanılmaktadır. 
Bunun yanı sıra öğretmen adaylarının yansıtıcı düşünme düzeylerini arttırabilmek için eğitim fakültelerinde yansıtıcı düşünme becerilerini geliştirmeye yönelik uygulamalı eğitim yapılabilir. $\mathrm{Bu}$ bağlamda kuram ve uygulama arasındaki ilişkinin canlı tutulmasına özen gösterilebilir. Öğretmen adaylarının yansıtıcı düşünme eğilimlerinin arttırılabilmesi için yapılacak çalışmalar kapsamında öncelikli olarak öğretim elemanları kendilerini yetiştirmelidir. Sosyal Bilgiler Programı, Ata'nın (2006) da belirttiği üzere; "oluşturmacı olduğu kadar yansitıcı düşünme yaklaşımlarıyla dinamik bir Sosyal Bilgiler sinıfi amaçlamakta, anlamlı ve aktif ögrenmeyi öngörmektedir". Bu hedefi de şüphesiz yansitıcı düşünme eğilimleri yüksek Sosyal Bilgiler öğretmenleri gerçekleştirecektir. 
KAYNAKÇA

Alp, S., \& Taşkın, Ş. Ç. (2008). "Eğitimde Yansıtıcı Düşünmenin Önemi ve Yansıtıcı Düşünmeyi Geliştirme”. Milli Eğitim Dergisi, 178, 311-320.

Altınok, H. (2002). "Yansıtıcı Öğretim: Önemi ve Öğretmen Eğitimine Yansımaları". Eğitim Araştırmalarl Dergisi, 7, 66-73.

Aslan, G. (2009). Sınıf Öğretmenlerinin Yansıtıcı Düşünme Eğilimleri ile Sürekli Kaygı Düzeyleri Arasındaki İlişkinin İncelenmesi. Yayınlanmamış Yüksek Lisans Tezi. Yeditepe Üniversitesi Sosyal Bilimler Enstitüsü, İstanbul.

Ata, B. (2006, Nisan). "Sosyal Bilgiler Eğitiminde Yansıtıcı Soruşturma Geleneği ve Oluşturmacılık Yaklaşımı”. Eğitimde Çă̆daş Yönelimler III: Yapılandırmacılık ve Ĕ̆itimde Yansımaları Sempozyumu, Özel Tevfik Fikret Okulları, İzmir.

Atay, D. Y. (2003). Öğretmen Ĕgitiminin Değişen Yüzü. Ankara: Nobel Yayın Dağıtım.

Aydın, M., \& Çelik, T. (2013). "Sosyal Bilgiler Oğretmen Adaylarının Yansıtıcı Düşünme Becerilerinin Bazı Değişkenler Açısından İncelenmesi”. Pamukkale Üniversitesi Eğitim Fakültesi Dergisi, 34/II, 169-181.

Dolapçığlu, S. D. (2007). Sınıf Öğretmenlerinin Yansıtıcı Düşünme Düzeylerinin Değerlendirilmesi. Yayınlanmamış Yüksek Lisans Tezi. Mustafa Kemal Üniversitesi Sosyal Bilimler Enstitüsü, Hatay.

Duban, N., \& Yelken T. Y. (2010). "Öğretmen Adaylarının Yansıtıcı Düşünme Eğilimleri ve Yansıtıcı Öğretmen Özellikleriyle İlgili Görüşleri”. Çukurova Üniversitesi Sosyal Bilimler Enstitüsü Dergisi, 19/2, 343-336.

Durdukoca, F. Ş., \& Demir, M. (2012). “İlköğretim Öğretmenlerin Bazı Değişkenlere Göre Yansıtıcı Düşünme Düzeyleri ve Düşüncelerindeki Öğretmen Niteliklerinin Yansıtıcı Öğretmen Niteliklerine Uygunluğu”. Mustafa Kemal Üniversitesi Sosyal Bilimler Enstitüsü, 9/20, 357-374.

Ekiz, D. (2006). "Kendini ve Başkalarını İzleme: Sınıf Öğretmeni Adaylarının Yansıtıcı Günlükleri”. Illkögretim-Online, 5/1, 45-57.

Erginel, S. Ş. (2006). Developing Reflective Teachers: A Study on Perception and Improvement of Reflection in Pre-Service Teacher Education. Yayınlanmamış Yüksek Lisans Tezi. Ortadoğu Teknik Üniversitesi Sosyal Bilimler Enstitüsü, Ankara.

Ersözlü, Z. N. (2008). Yansıtıcı Düşünmeyi Geliştirici Etkinliklerin İlköğretim 5. Sinıf Öğrencilerinin Sosyal Bilgiler Dersindeki Akademik Başarılarına ve Tutumlarına Etkisi. Yayınlanmamış Doktora Tezi. Frrat Üniversitesi Sosyal Bilimler Enstitüsü, Elazı ̆̆.

Genç, B. (2004). "The Nature of Reflective Thinking and Its Implications for In-Service Teacher Education”. Çukurova Üniversitesi Sosyal Bilimler Enstitüsü Dergisi, 13, 235-243.

Güvenç, Z. (2012). Sınıf Öğretmenlerinin Duygusal Zekâları İle Yansıtıcı Düşünme Becerileri Arasındaki Illişki. Yayınlanmamış Yüksek Lisans Tezi. Pamukkale Üniversitesi Sosyal Bilimler Enstitüsü, Denizli.

Hasırcı, K. Ö., \& Sadık, F. (2011). "Sınıf Öğretmenlerının Yansıtıcı Düşünme Eğilimlerinin İncelenmesi”. Ç.Ü. Sosyal Bilimler Enstitüsü Dergisi, 20/2, 195-210.

İnönü, Y. (2006). Tarih Öğretmenlerinin Yansitici Öğretmen Özelliklerine Sahiplik Düzeyi (Van Örneği). Yayınlanmamış Yüksek Lisans Tezi. Yüzüncü Yıl Üniversitesi Sosyal Bilimler Enstitüsü, Van.

Karadağ, M. (2010). Sosyal Bilgiler Öğretmenlerinin Yansıtıcı Düşünme Düzeylerinin İncelenmesi (Şanlıurfa İli Örneği). Yayınlanmamış Yüksek Lisans Tezi. Çukurova Üniversitesi Sosyal Bilimler Enstitüsü, Adana.

Karasar, N. (2003). Bilimsel Araştırma Yöntemi (12. Baskı). Ankara: Nobel Yayın Dağıtım.

Kirk, R. (2000). "A Study of the Use of a Private Chat Room to Increase Reflective Thinking in PreService Teachers". College Student Journal, 34/1, 8-18.

Kozan, S. (2007). Yansıtıcı Düşünme Becerisinin Kaynak Tarama ve Rapor Yazma Derslerindeki Etkisi Yayınlanmamış Yüksek Lisans Tezi. Selçuk Üniversitesi Sosyal Bilimler Enstitüsü, Konya.

Köksal, N., \& Demirel, Ö. (2008). "Yansıtıcı Düşünmenin Öğretmen Adaylarının Öğretmenlik Uygulamalarına Katkıları”. Hacettepe Üniversitesi Eğitim Fakültesi Dergisi, 34, 189-203. 
Langer, A. M. (2002). "Reflecting on Practice: Using Learning Journals in Higher and Continuing Education". Teaching in Higher Education, 7/3, 337-351.

Lee, H. J. (2005). "Understanding and Assessing Preservice Teachers' Reflective Thinking”. Teaching and Teacher, 21/1, 699-715.

Oruç, İ. (2000). Effects of Reflective Teacher Training Program on Teachers' Perception of Classroom Environment and on Their Attitudes Toward Teaching Profession. Yayınlanmamış Yüksek Lisans Tezi. Ortadoğu Teknik Üniversitesi Sosyal Bilimler Enstitüsü, Ankara.

Özmen, C. (2011). "Sosyal Bilgiler Eğitiminde Yansıtıı İnceleme Yaklaşımına İlişkin Öğretmen Görüşleri”. Sosyal Bilimler Enstitüsü Dergisi, 30/1, 61-81.

Öztürk S. (2003). Developing a Reflective Reading Model. Yayınlanmamış Yüksek Lisans Tezi. Marmara Üniversitesi Eğitim Bilimleri Enstitüsü, İstanbul.

Semerci, Ç. (2007). "Öğretmen ve Öğretmen Adayları için Yansıtııı Düşünme Eğilimi (YANDE) Ölçeğinin Geliştirilmesi”. Kuram ve Uygulamada Eğitim Bilimleri, 7/3, 729-752.

Semerci, N. (1999). Kritik Düşünmenin Mikro Öğretim Dersinde Eleştiri Becerisini Geliştirmeye Etkisi. Yayınlanmamış Doktora Tezi. Fırat Üniversitesi Sosyal Bilimler Enstitüsü, Elazığ.

Şahan, H. H., \& Kalkay, İ. (2011, Ekim). Öğretmen Adaylarının Sahip Olduğu Yansitıcı Düşünme Eğilimleri. Sözel Bildiri, I. Uluslararası Eğitim Programları ve Öğretim Kongresi, Anadolu Üniversitesi, Eskişehir. 30.11.2014 tarihinde şu kaynaktan alınmıştır: http://www.pegem.net/ akademi/kongrebildiri_detay.aspx?id=129972

Şahin, A. (2011). "Türkçe Öğretmeni Adaylarının Yansıtıcı Düşünme Eğilimlerinin Çeşitli Değişkenlere Göre Değerlendirilmesi”. Elektronik Sosyal Bilimler Dergisi, 10/37, 108-119.

Tok, Ş. (2008). "Yansıtıcı Düşünmeyi Geliştirici Etkinliklerin Öğretmen Adaylarının Öğretmenlik Mesleğine Yönelik Tutumlarına, Performanslarına ve Yansıtmalarına Etkisi”. Eğitim ve Bilim, 33/149, 104-117.

Ünver, G. (2003). Yansıtıcı Düşünme. Ankara: Pegem A Yayıncılık.

Üstün, G. (2011). Sinıf Öğretmenlerinin Yansitıcı Düşünme Eğilimleri İle Demokratik Tutumları Arasındaki İlişkinin İncelenmesi. Yayınlanmamış Yüksek Lisans Tezi. Marmara Üniversitesi Eğitim Bilimleri Enstitüsü, İstanbul.

Yorulmaz, M. (2006). Illköğretim I. Kademesinde Görev Yapan Sinlf Öğretmenlerinin Yansitıcı Düşünmeye İlişkin Görüş ve Uygulamalarının Değerlendirilmesi (Diyarbakır İli Örneği). Yayınlanmamış Yüksek Lisans Tezi. Fırat Üniversitesi Sosyal Bilimler Enstitüsü, Elazığ. 